\title{
Evaluation of graphene oxide and reduced graphene oxide in the immobilization of laccase enzyme and its application in the determination of dopamine
}

\author{
Natália Akemi Kohori ${ }^{1}$ - Martin Kássio Leme da Silva ${ }^{1} \cdot$ Ivana Cesarino $^{1}$
}

Received: 2 May 2017 / Revised: 24 July 2017 / Accepted: 17 August 2017 / Published online: 24 August 2017

(C) Springer-Verlag GmbH Germany 2017

\begin{abstract}
Bioelectrodes were developed based on a simple deposition of graphene oxide (GO) or reduced graphed oxide (rGO) and laccase (Lac) on a glassy carbon (GC) electrode surface. The morphology and electrochemical behavior of the biosensors were characterized by scanning electron microscopy and cyclic voltammetry. These results demonstrated that only rGO was successfully applied for the immobilization of the laccase enzyme, improving the analytical signal for the determination of dopamine. The $\mathrm{GC} / \mathrm{rGO} / \mathrm{Lac}$ biosensor was applied to the detection of dopamine in synthetic urine and plasmatic serum samples, achieving a detection limit of $91.0 \mathrm{nmol} \mathrm{L}^{-1}$.
\end{abstract}

Keywords Biosensors $\cdot$ Graphene $\cdot$ Laccase $\cdot$ Dopamine

\section{Introduction}

Biosensors are devices that recognize and detect some physical or chemical property, turning it into a useful signal that shows quantitative or qualitative information about the sample. The prefix "bio" indicates that the recognition system is constituted by biochemical or biological mechanisms $[1,2]$. This structure can be formed by several biological elements like enzymes, cofactors, or whole cells, including antibodies and microorganisms [3], all of which are used to endow the sensors with specificity and sensitivity.

Ivana Cesarino

ivana@fca.unesp.br

1 School of Agriculture, Sao Paulo State University (UNESP), Botucatu, SP, Brazil
In 1962, Clark and Lyons introduced the concept of the first electrode with immobilized enzymes, and since then, enzymes have been the main recognition elements used in biosensors $[4,5]$. Thus, to develop biosensors based on enzymes, enzymatic immobilization techniques are required to provide the retention of enzymes in some regions or materials, allowing the catalytic activity to be continuously repeated.

The enzymatic immobilization improves properties such as reuse and stabilization but causes problems on sensor surfaces, and for this reason, many different strategies and methods such as physical adsorption, entrapment, covalent bonding, and affinity immobilization are used [6]. However, some methods rely on binding agents, which can cover the enzyme's active sites, causing deformation and even making it unavailable to the substrate, reducing its activity and modifying its kinetics and properties. Therefore, the combination of laccase (Lac) and graphene without binding agents will be used in the biosensor preparation.

Laccase is a multicopper oxidase whose appeal is that the copper atoms in the enzyme active site perform a direct electron transfer with the electrode [7]. This biocatalyst will increase the sensitivity and specificity as well as enhancing the analytical signal that will be read by the sum of the chemical and electrochemical processes, resulting in a higher current response.

Graphene is a recently discovered allotrope of graphite; it offers promise for technological innovation and has attracted scientific interest in recent years [8]. In the field of electronics, its applications include energy conversion and storage to create supercapacitors [9], batteries [10], fuel cells [11], solar cells [12], and electrochemical sensors [13]. Due to its unique physicochemical properties such as a single-atom thickness, high surface area $[14,15]$, strong mechanical resistance [16], excellent electrical [15, 17], and thermal conductivity [18], graphene is associated with a sensitivity improvement in 
biosensors. In addition, the chemical production method is mostly used in electrochemistry, and the reduced graphene oxide ( $\mathrm{rGO}$ ) is obtained through formation of graphene oxide (GO). This graphene is called "functionalized graphene sheets" or "chemically reduced graphene oxide." It has many structural defects $[14,19]$ and functional groups [20], providing advantages for electrochemical applications.

Several authors have successfully applied rGO and GO as supporting materials for laccase and other enzyme immobilization. Mei et al. [21] developed a biosensor based on laccase immobilized on rGO supported palladium-copper alloyed nanocages for phenol determination. Cincotto et al. [22] used a hybrid nanomaterial based on $\mathrm{GO}-\mathrm{Sb}_{2} \mathrm{O}_{5}$ to immobilize laccase for determining estriol. In addition, Boujakhrout et al. [23] used a new nanohybrid based on rGO-glycol chitosan. Hong et al. [24] reported the use of GO for glucose oxidase immobilization for sensitive biosensing. Different methodologies, such as enzyme adsorption and cross-linking, were applied.

Thereby, laccase can be immobilized in GO and rGO to evaluate and determine dopamine, an important neurotransmitter that is chemically oxidized to dopamine $o$-quinone form, followed by electrochemical reduction [25].

Neurotransmitters are responsible for body signals that act on the nervous system and are related to recurrent diseases. Dopamine is a catecholamine that is strongly linked to illnesses like Parkinson's disease, schizophrenia, and depression as well as behavior syndromes such as Huntington's disease, Tourette's syndrome, and hyperprolactinemia [26]. It is involved in several neural and physiological processes such as motor development, movement control, reward system, memory, and many others, and therefore, the determination of dopamine levels in biological samples is important for clinical diagnosis and early treatment [27]. Thus, glassy carbon/ reduced graphene oxide/laccase $(\mathrm{GC} / \mathrm{rGO} / \mathrm{Lac})$ biosensor will be evaluated and applied in nanobiotechnological sensors to provide knowledge of new materials, improving the sensitivity, strength, and applicability for determination of neurotransmitters, in particular dopamine.

\section{Materials and methods}

\section{Chemicals and solutions}

All solutions were prepared with water purified from a Millipore ultrapure water system with resistivity $\geq 18 \mathrm{M} \Omega$ $\mathrm{cm}$ (Millipore). All reagents used in this study were of analytical grade and were used without further purification. GO, laccase from Trametes versicolor $(\geq 0.5 \mathrm{U} / \mathrm{mg}$ of light brown powder, EC-1.10.3.2), and dopamine were purchased from Sigma-Aldrich (Germany).

\section{Apparatus and procedures}

Cyclic voltammetry (CV) and differential pulse voltammetry (DPV) experiments were performed using a model PGSTAT128N Autolab electrochemical system (Metrohm) equipped with NOVA 2.0 software (Metrohm). The cell was assembled with a conventional three-electrode electrochemical system: bare $\mathrm{GC}, \mathrm{GC} / \mathrm{rGO}$, or $\mathrm{GC} / \mathrm{rGO} / \mathrm{Lac}$ as the working electrode (diameter: $3 \mathrm{~mm}), \mathrm{Ag} / \mathrm{AgCl} / \mathrm{KCl}\left(3.0 \mathrm{~mol} \mathrm{~L}^{-1}\right)$ as the reference electrode, and a Pt plate as the auxiliary electrode. All experiments were carried out at a controlled temperature $\left(25 \pm 1^{\circ} \mathrm{C}\right)$. Electrochemical characterization of the $\mathrm{GC} / \mathrm{rGO} / \mathrm{Lac}$ electrode was performed using $\mathrm{CV}$ in $0.2 \mathrm{~mol} \mathrm{~L}^{-1}$ phosphate buffer solution (PBS) (pH 7.0) with a scan rate of $50 \mathrm{mV} \mathrm{s}^{-1}$. DPV measurements were obtained with a scan rate of $10 \mathrm{mV} \mathrm{s}^{-1}$, pulse amplitude of $100 \mathrm{mV}$, and a step potential of $5 \mathrm{mV}$ in PBS (pH 7.0) containing $10.0 \mu \mathrm{mol} \mathrm{L} \mathrm{L}^{-1}$ of dopamine standard. The electrochemical impedance spectroscopy (EIS) spectra were scanning from $10^{7}$ to $10^{-2} \mathrm{~Hz}$ frequency range and $10 \mathrm{mV}$ amplitude, with 20 data points per frequency decade. The impedance spectra were recorded in open circuit potential (OCP) conditions in $0.1 \mathrm{~mol} \mathrm{~L}^{-1} \mathrm{KCl}$ solution (pH 7.4) containing $5.0 \mathrm{mmol} \mathrm{L}^{-1}$ $\left[\mathrm{Fe}(\mathrm{CN})_{6}\right]^{3-/ 4-}$. Fitting and calculation to equivalent electrical circuit, $R_{s}, C P E$, and $\alpha$ and $R_{c t}$ values were performed using electrochemical circle fit tool in Nova 2.0 software. The surface morphology of each material was characterized by scanning electron microscopy (SEM), and the images were recorded using a model Quanta 200 (FEI Company, Hillsboro, USA).

\section{Synthesis of the reduced graphene oxide (rGO)}

Briefly, $5.0 \mathrm{~mL}$ of the $\mathrm{GO}$ dispersion $(4.0 \mathrm{mg} / \mathrm{mL})$ was mixed with $15.0 \mathrm{~mL}$ of ethanol (pure grade) and $16.0 \mathrm{mg}$ of sodium dodecyl sulfate and sonicated for $20 \mathrm{~min}$. Then, $8.0 \mathrm{mg}$ of sodium borohydride was added to the solution and the suspension was sonicated for a further $20 \mathrm{~min}$. The solution was then centrifuged and cleaned several times with ethanol. The resulting $\mathrm{rGO}$ composite was dried at $70{ }^{\circ} \mathrm{C}$. After this step, the $\mathrm{rGO}$ was dispersed in ultrapure water at a concentration of $0.3 \mathrm{mg} / \mathrm{mL}$.

\section{Preparation of the GC/rGO/Lac and GC/GO/Lac biosensors}

The glassy carbon (GC) electrodes were polished with $0.3-\mu \mathrm{m}$ alumina slurry, sonicated for $5 \mathrm{~min}$ in ethanol and $5 \mathrm{~min}$ in ultrapure water, and then dried at room temperature.

For preparation of the $\mathrm{GC} / \mathrm{rGO} / \mathrm{Lac}$ and $\mathrm{GC} / \mathrm{GO} / \mathrm{Lac}$ biosensors, $0.3 \mathrm{mg}$ of laccase from $T$. versicolor was mixed with $1.0 \mathrm{~mL}$ of the rGO solution $(0.3 \mathrm{mg} / \mathrm{mL})$ or $1.0 \mathrm{~mL}$ of the $\mathrm{GO}$ solution $(0.3 \mathrm{mg} / \mathrm{mL})$ in an Eppendorf tube. On the surfaces of 
the cleaned GC electrodes, $10 \mu \mathrm{L}$ of $\mathrm{rGO} / \mathrm{Lac}$ or $\mathrm{GO} / \mathrm{Lac}$ composite was dropped, then the biosensor was dried at room temperature.

\section{Sample preparation and analysis of dopamine in synthetic urine and plasmatic serum}

Krebs-Ringer solution and PBS samples, which are similar to plasmatic serum, were used. The artificial body fluid was prepared by a procedure similar to one previously described [28] as follows. A solution composition containing $6.98 \mathrm{~g}$ of $\mathrm{NaCl}$, $0.36 \mathrm{~g}$ of $\mathrm{KCl}, 0.28 \mathrm{~g}$ of $\mathrm{CaCl}_{2}, 0.15 \mathrm{~g}$ of $\mathrm{MgSO}_{4}$, and $210 \mathrm{~mL}$ of PBS (pH 7.0) in $1 \mathrm{~L}$ of solution was prepared. Known amounts of the standard dopamine solution were added to this solution, giving a final dopamine concentration of $0.5 \mu \mathrm{mol} \mathrm{L}{ }^{-1}$. No further sample treatment was done. The dopamine content was determined by four successive additions of aliquots of the standard dopamine solution.

The synthetic urine was prepared by a procedure similar to that described by Laube et al. [29]. The solution components are $1.10 \mathrm{~g}$ of $\mathrm{CaCl}_{2} \cdot 2 \mathrm{H}_{2} \mathrm{O}, 2.92 \mathrm{~g}$ of NaCl, $2.25 \mathrm{~g}$ of $\mathrm{Na}_{2} \mathrm{SO}_{4}$, $1.40 \mathrm{~g}$ of $\mathrm{KH}_{2} \mathrm{PO}_{4}, 1.60 \mathrm{~g}$ of KCl, $1.00 \mathrm{~g}$ of $\mathrm{NH}_{4} \mathrm{Cl}, 25.00 \mathrm{~g}$ of urea, and $1.10 \mathrm{~g}$ of creatine at $\mathrm{pH} 7.0$ per liter of ultrapure water. Again, known amounts of the standard dopamine solution were added to this solution, giving a final dopamine concentration of $0.5 \mu \mathrm{mol} \mathrm{L}{ }^{-1}$. No further sample treatment was done. The dopamine content was determined by four successive additions of aliquots from standard dopamine solution.

\section{Results and discussion}

\section{Morphological characterization of the composites}

The morphology of the GO, rGO, GO/Lac, and $\mathrm{rGO} / \mathrm{Lac}$ was studied by SEM analysis, as presented in Fig. 1. Figure 1a displays images of GO, where it can be observed that the material consists of a mixture of single layers and multilayer graphene sheets. On the other hand, Fig. 1b presents the images of $\mathrm{rGO}$, in which the material displays a wrinkled structure with plenty of corrugations. The reduction of GO causes the unstacking of sheets and, consequently, the unblocking of active sites [30]. Figure 1c shows the images of the $\mathrm{rGO} / \mathrm{Lac}$ composite, where it is possible to observe the immobilization of the laccase onto rGO. The structural defects $[14,19]$ of rGO facilitate the immobilization of the laccase as a covalent attachment, but without the use of bi-functional groups or spacers such as glutaraldehyde and aminopropyltriethoxysilanes. The use of rGO to immobilize the enzymes is a simple, cheap, and less aggressive immobilization procedure for biomolecules. Finally, Fig. 1d presents the images of $\mathrm{GO} / \mathrm{Lac}$, revealing that $\mathrm{GO}$ was modified by the enzyme. The laccase is immobilized in the GO by physical
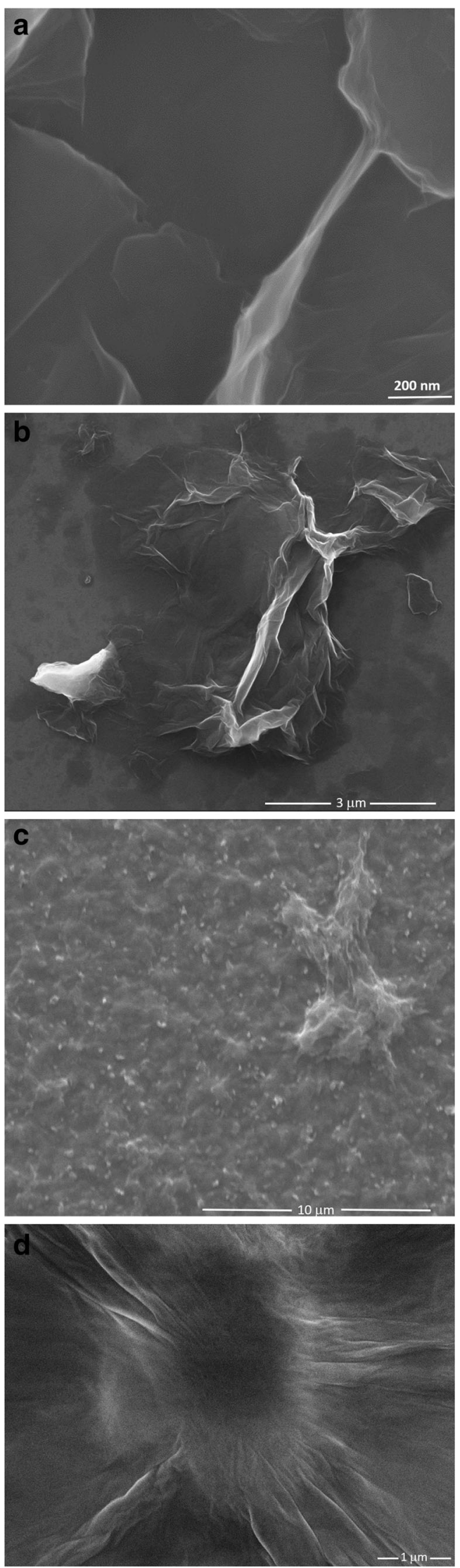

Fig. 1 FEG-SEM micrographs for a GO, b rGO, $\mathbf{c r G O}$ /Lac, and $\mathbf{d} \mathrm{GO} /$ Lac 
adsorption by the interactions of $\pi-\pi$ stacking between the rings of GO and those of any aromatic amino acids exposed on the surface of the protein. This immobilization relies on weak physical forces, which can affect the stability of the enzyme.

\section{Electrochemical characterization of GO and rGO}

$\mathrm{CV}$ experiments in the presence of the $\left[\mathrm{Fe}(\mathrm{CN})_{6}\right]^{3-} /{ }^{4-}$ redox couple were performed for the electrochemical characterization of the materials. Figure 2 shows the voltammetric profiles for the two different electrodes: (a) $\mathrm{GC} / \mathrm{GO}$ and (b) $\mathrm{CG} / \mathrm{rGO}$ in $0.2 \mathrm{~mol} \mathrm{~L}^{-1} \mathrm{PBS} \mathrm{pH} 7.4,0.1 \mathrm{~mol} \mathrm{~L}^{-1} \mathrm{KCl}$ containing $5.0 \mathrm{mmol} \mathrm{L}^{-1}$ of the redox couple $\left[\mathrm{Fe}\left(\mathrm{CN}_{6}\right)\right]^{3-/ 4-}$ with a scan rate of $50 \mathrm{mV} \mathrm{s}^{-1}$.

The voltammetric profiles show well-defined oxidation and reduction peaks for the $\mathrm{GC} / \mathrm{GO}$ and $\mathrm{GC} / \mathrm{rGO}$ electrodes due to the $\mathrm{Fe}^{3+} / \mathrm{Fe}^{2+}$ redox couple in identical potentials of approximately +0.29 and $+0.18 \mathrm{~V}$ vs. $\mathrm{Ag} / \mathrm{AgCl} / \mathrm{KCl}$ ( $3 \mathrm{~mol} \mathrm{~L}^{-1}$ ), respectively. However, the $\mathrm{GC} / \mathrm{rGO}$ electrode (curve b) showed a 1.9-fold increase in the peak current compared to the $\mathrm{GC} / \mathrm{GO}$ electrode (curve a). This increase is due to the presence of defects introduced in its structure, as well less oxygen atoms increase the electron transport.

The electrochemical enhanced properties of GO and rGO were also verified using EIS in order to quantify the chargetransfer resistance values for the electrode process. Figure 3 displays the current response for $\mathrm{GC} / \mathrm{GO}$ and $\mathrm{GC} / \mathrm{rGO}$ in the presence of $5.0 \mathrm{mmol} \mathrm{L}^{-1}$ of the redox couple. Nyquist plots were used to analyze EIS data and presented with the equivalent circuit inset, as shown in Fig. 3. The EIS plots exhibited $R_{\mathrm{S}}$ for $\mathrm{GC} / \mathrm{GO}$ about $8.06 \Omega$, which was larger than $\mathrm{GC} / \mathrm{rGO}$ (4.84 $\Omega$ ). The fitted value of $R_{\mathrm{ct}}$ obtained for $\mathrm{GC} / \mathrm{GO}$ and $\mathrm{GC} /$ rGO was $81.45 \Omega$ and $61.74 \Omega$, respectively. The lower value of $R_{\mathrm{ct}}$ for rGO was also observed in recent publications [31, $32]$, indicating the improvement in electron transfer of this

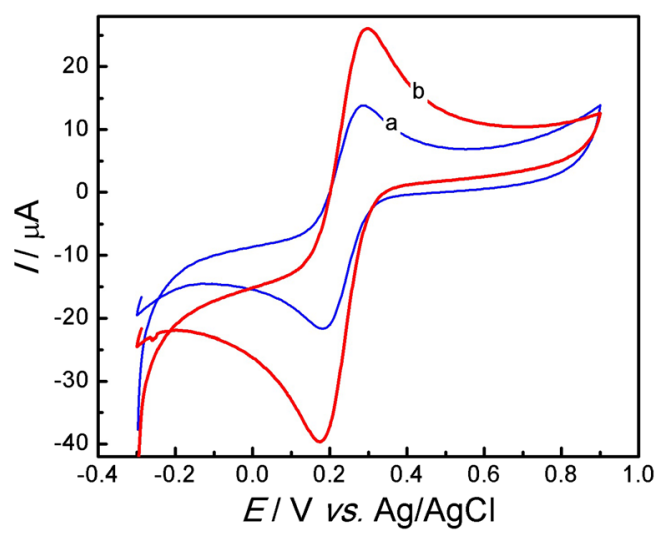

Fig. $2 \mathrm{CV}$ scans of the electrodes: (a) GC/GO and (b) GC/rGO in $0.2 \mathrm{~mol} \mathrm{~L}^{-1} \mathrm{PBS} \mathrm{pH} 7.4,0.1 \mathrm{~mol} \mathrm{~L}^{-1} \mathrm{KCl}$ containing $5.0 \mathrm{mmol} \mathrm{L}^{-1}$ of the redox couple $\left[\mathrm{Fe}\left(\mathrm{CN}_{6}\right)\right]^{3-/ 4-}$ with a scan rate of $50 \mathrm{mV} \mathrm{s}^{-1}$

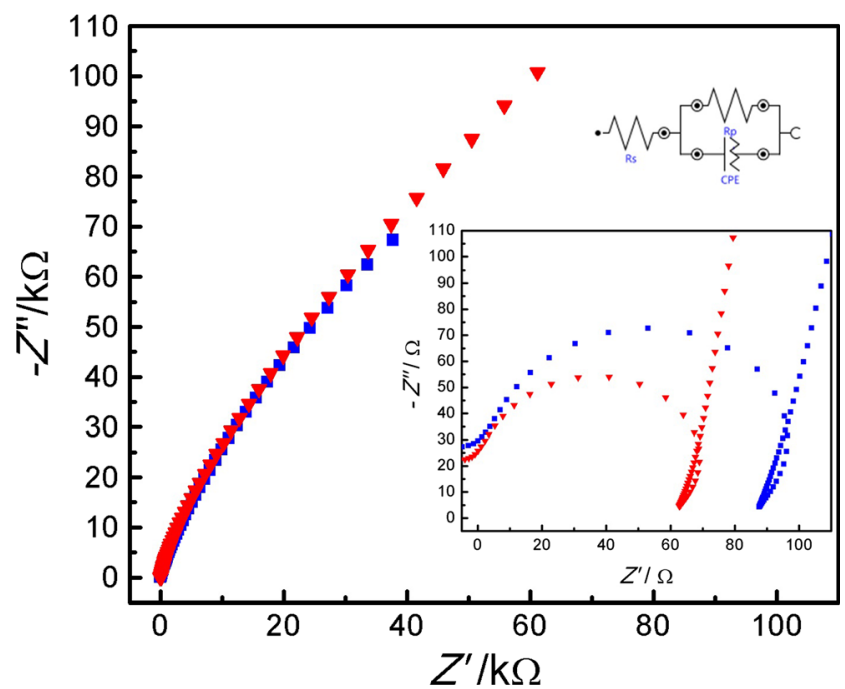

Fig. 3 Nyquist diagram for $\mathrm{GC} / \mathrm{GO}(\boldsymbol{\nabla})$ and $\mathrm{GC} / \mathrm{rGO}(\boldsymbol{\bullet})$. Insets: High frequency interval and electrical equivalent circuit. The solution is $0.2 \mathrm{~mol} \mathrm{~L}^{-1} \mathrm{PBS} \mathrm{pH} 7.4,0.1 \mathrm{~mol} \mathrm{~L}^{-1} \mathrm{KCl}$ containing $5.0 \mathrm{mmol} \mathrm{L}^{-1}$ of the redox couple $[\mathrm{Fe}(\mathrm{CN} 6)]^{3-/ 4}$

material. This behavior is in agreement with $\mathrm{CV}$ experiments that rGO has a higher peak current response for the redox couple.

\section{Electrochemical characterization of the enzymatic biosensors in the dopamine process}

The electrochemical behavior of dopamine toward the $\mathrm{GC} /$ $\mathrm{rGO} / \mathrm{Lac}$ biosensor was investigated in $0.2 \mathrm{~mol} \mathrm{~L}^{-1}$ of PBS pH 7.0 containing $10.0 \mu \mathrm{mol} \mathrm{L}^{-1}$ of dopamine by cyclic voltammetry experiments at a scan rate of $50 \mathrm{mVs}^{-1}$, as presented in Fig. 4. An electrochemical process at a potential of

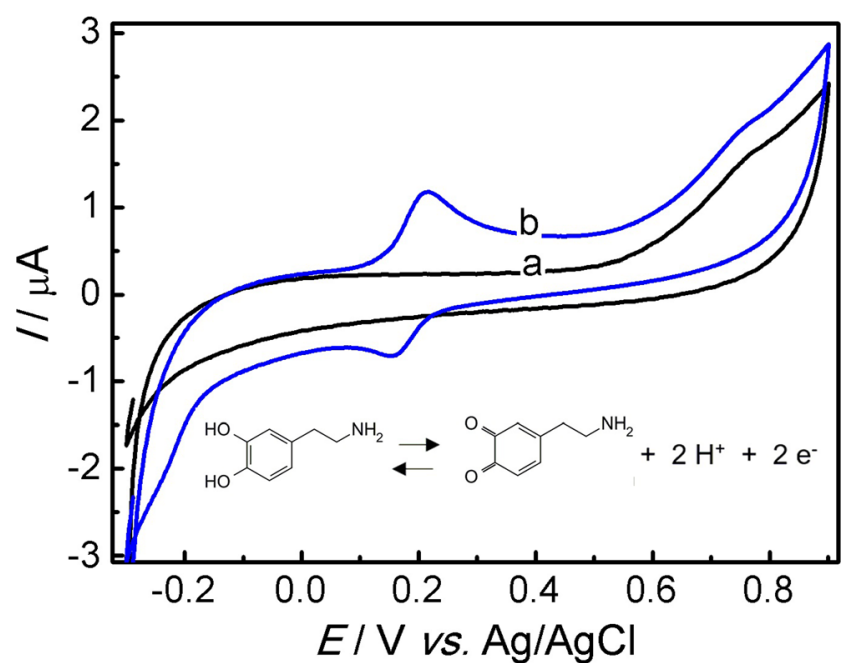

Fig. $4 \mathrm{CV}$ scans of the $\mathrm{GC} / \mathrm{rGO} / \mathrm{Lac}$ biosensor in $0.2 \mathrm{~mol} \mathrm{~L}^{-1} \mathrm{PBS}$ $\mathrm{pH} 7.0$ in the absence (curve $a$ line) and in the presence (curve b) of $10.0 \mu \mathrm{mol} \mathrm{L}{ }^{-1}$ of dopamine with a scan rate of $50 \mathrm{mV} \mathrm{s}^{-1}$. Inset: electrochemical mechanism for dopamine oxidation 
approximately $+750 \mathrm{mV}$ was observed for the $\mathrm{GC} / \mathrm{rGO} / \mathrm{Lac}$ biosensor in the absence (curve a) and in the presence (curve b) of dopamine, and this process was attributed to the $\mathrm{rGO} / \mathrm{Lac}$ composite. However, in the presence of dopamine, the proposed bioelectrode also presented processes of reduction and oxidation of dopamine at potentials of +150 and $+220 \mathrm{mV}$, respectively, with the mechanism shown in the inset of Fig. 4.

DPV experiments were performed in the same solution as described above for the electrodes, and the results for $\mathrm{GC}$ (curve a), GC/GO (curve b), GC/rGO (curve c), GC/GO/Lac (curve d), and GC/rGO/Lac (curve e) are shown in Fig. 5. It was observed that the five electrodes presented reduction peaks at approximately $+190 \mathrm{mV}$, but the $\mathrm{GC} / \mathrm{rGO} / \mathrm{Lac}$ biosensor (curve e) showed a higher cathodic current in comparison to the currents observed in the other electrodes, revealing the efficient immobilization of the laccase enzyme in the rGO. On the other hand, the GC/GO/Lac biosensor (curve d) exhibited the lowest cathodic peak current for the dopamine. This is due to the absence of structural defects on GO sheets which can interfere in the laccase efficiently immobilization. Also, GO has more oxygen atoms than rGO and actually has more functional groups that decrease the electron transport.

Thus, the cathodic peak current for dopamine was lower than that obtained with the bare GC electrode (curve a).

Several reports show that the use of cross-linked agents, such as glutaraldehyde or diimide, can inhibit the active sites of enzymes, inhibiting their activity [33]. Since no electrodeposition or secondary immobilization step was used, the immobilization of $\mathrm{rGO} / \mathrm{Lac}$ film onto the surface of the GC electrode was very fast and practical, which made it a better analytical device. The DPV experiment shows that the GC/rGO/Lac biosensor increased the cathodic peak by a factor of 1.9 compared with $\mathrm{GC} / \mathrm{rGO}$ electrode; that is, $I_{\mathrm{pc}}$ is almost double for the bioelectrode. This increase in the cathodic peak current is due to the sum of the dopamine $o$-quinone reduction processes formed from chemical and electrochemical steps. One part of this reduction process

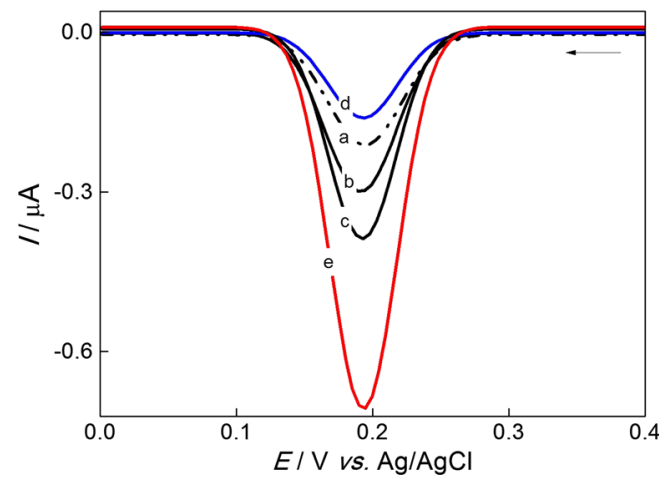

Fig. 5 DPV voltammograms in $0.2 \mathrm{~mol} \mathrm{~L}^{-1} \mathrm{PBS} \mathrm{pH} 7.0$, containing $10.0 \mu \mathrm{mol} \mathrm{L}{ }^{-1}$ of dopamine for the following electrodes: $(a)$ bare $\mathrm{GC}$, (b) $\mathrm{GC} / \mathrm{GO},(c) \mathrm{GC} / \mathrm{rGO},(d) \mathrm{GC} / \mathrm{GO} / \mathrm{Lac}$, and $(e) \mathrm{GC} / \mathrm{rGO} / \mathrm{Lac}$ is the laccase effect, in which dopamine was chemically oxidized to dopamine $o$-quinone, followed by electrochemical reduction. The other contribution is the reduction of the dopamine $o$-quinone in the electrochemical step [34]. When the $\mathrm{GC} / \mathrm{rGO} / \mathrm{Lac}$ biosensor is compared with the other electrodes, the cathodic peak increased by factors of 3.4 and 2.4 in relation to bare $\mathrm{GC}$ and $\mathrm{GC} / \mathrm{GO}$, respectively.

\section{Optimization of laccase concentration in the biosensor preparation}

To maximize the DPV analytical signals, the concentration of laccase in the composition of the bioelectrode was optimized in the range of 0.1 to $0.4 \mathrm{mg} \mathrm{mL}^{-1}$, in $0.2 \mathrm{~mol} \mathrm{~L}^{-1}$ of PBS $\mathrm{pH} 7.0$ containing $5.0 \mu \mathrm{mol} \mathrm{L} \mathrm{L}^{-1}$ of dopamine, and the results are presented in Fig. 6. The cathodic peak current increased with the amount of laccase enzyme on the electrode surface up to the amount of $0.3 \mathrm{mg} \mathrm{mL}^{-1}$, at which the maximum current was reached. For quantities above this value, the cathodic peak current decreases. This is due to the decrease in the conductive area of the biosensor. Therefore, according to these results, $0.3 \mathrm{mg}$ of laccase was used in the preparation of the biosensor.

\section{Analytical performance of GC/rGO/Lac biosensor}

In order to evaluate the performance of the proposed biosensor, DPV experiments were carried out with different concentrations of dopamine. The range of potential was adjusted from 0.5 to $0.0 \mathrm{~V}$ (vs. $\mathrm{Ag} / \mathrm{AgCl}$ ), and the figures of merit were found. The DPV experiments showed a linear increase in the cathodic peak currents

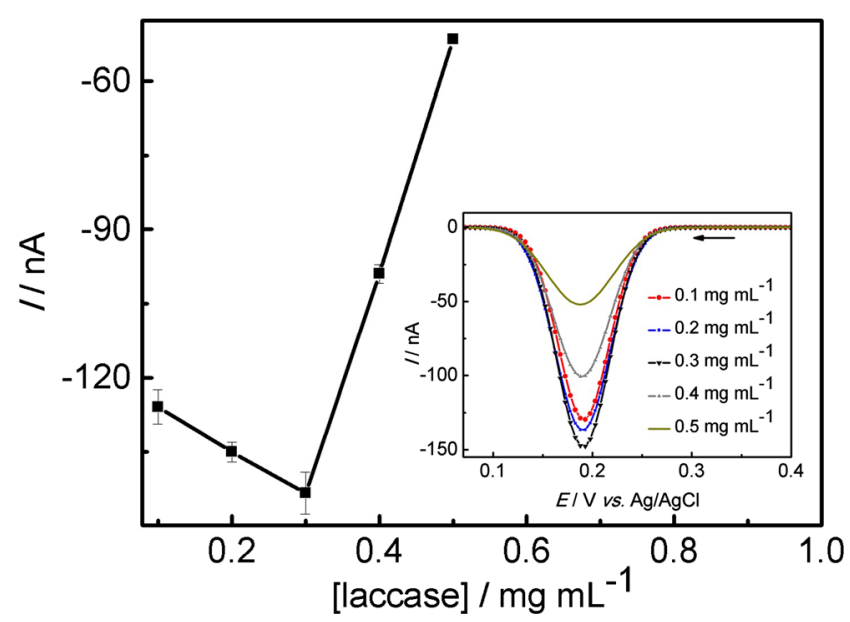

Fig. 6 Effect of the concentration of enzyme in the biosensor composition. Inset: DPV experiments in $0.2 \mathrm{~mol} \mathrm{~L}^{-1} \mathrm{PBS} \mathrm{pH} 7.0$ containing $5.0 \mu \mathrm{mol} \mathrm{L}{ }^{-1}$ of dopamine for the $\mathrm{GC} / \mathrm{rGO} / \mathrm{Lac}$ biosensor with the concentration of laccase in the range of 0.1 to $0.5 \mathrm{mg} \mathrm{mL}^{-1}$ 
when the concentration of dopamine was variated from 0.1 to $3.0 \mu \mathrm{M}$ (Fig. 7), as described in Eq. 1:

$I_{p c}(\mathrm{nA})=-2.07(\mathrm{nA})-27.08\left(\mathrm{nA} / \mu m o l \mathrm{~L}^{-1}\right)[$ dopamine $]\left(\mu m o l \mathrm{~L}^{-1}\right)$

with a correlation coefficient of $0.998(n=7)$. The limit of detection (LOD) obtained was $91 \mathrm{nmol} \mathrm{L}^{-1}\left(14.0 \mu \mathrm{g} \mathrm{L}^{-1}\right)$, which was determined using a $3 \mathrm{~s} / \mathrm{slope}$ ratio, where $\mathrm{s}$ is the standard deviation of the mean value for 10 voltammograms of the blank. The LOD value determined by the proposed biosensor is adequate to monitor dopamine in urine, since the concentration of dopamine found in urine ranges from 51 to $645 \mu \mathrm{g} / 24 \mathrm{~h}$, depending on the age of the individual [35]. In plasma samples, the reference ranges for dopamine are lower.

The advantages of the $\mathrm{GC} / \mathrm{rGO} / \mathrm{Lac}$ biosensor are its easy preparation, repeatability, and stability in the experiments. In order to perform a repeatability test, ten DPV voltammograms were obtained in $0.2 \mathrm{~mol} \mathrm{~L}^{-1}$ of PBS pH 7.0 containing $10.0 \mu \mathrm{mol} \mathrm{L}^{-1}$ of dopamine using the same working electrode. The relative standard deviation (RSD) was calculated as $2.1 \%$. In order to test the biosensor stability, it was stored in $0.20 \mathrm{~mol} \mathrm{~L}^{-1}$ of PBS (pH 7.0) at $4{ }^{\circ} \mathrm{C}$ and used daily in DPV experiments performed in $0.2 \mathrm{~mol} \mathrm{~L}^{-1}$ of PBS (pH 7.0) containing $2.0 \mu \mathrm{mol} \mathrm{L} \mathrm{L}^{-1}$ of dopamine for up to 30 days. After 1 month, the electrode had lost only $10.3 \%$ of its activity, which represents very reasonable stability for this kind of biosensor.

Dopamine has been determined by several modified electrodes with large range of LOD, such as carbon paste modified with ionic liquid $\left(0.70 \mu \mathrm{mol} \mathrm{L}^{-1}\right)$ [36], nanocomposite based on AuNPs/polyaniline core shell $\left(5.0 \mu \mathrm{mol} \mathrm{L}^{-1}\right)$ [37], sonogel-carbon electrodes $\left(0.16 \mu \mathrm{mol} \mathrm{L}^{-1}\right)$ [38], and

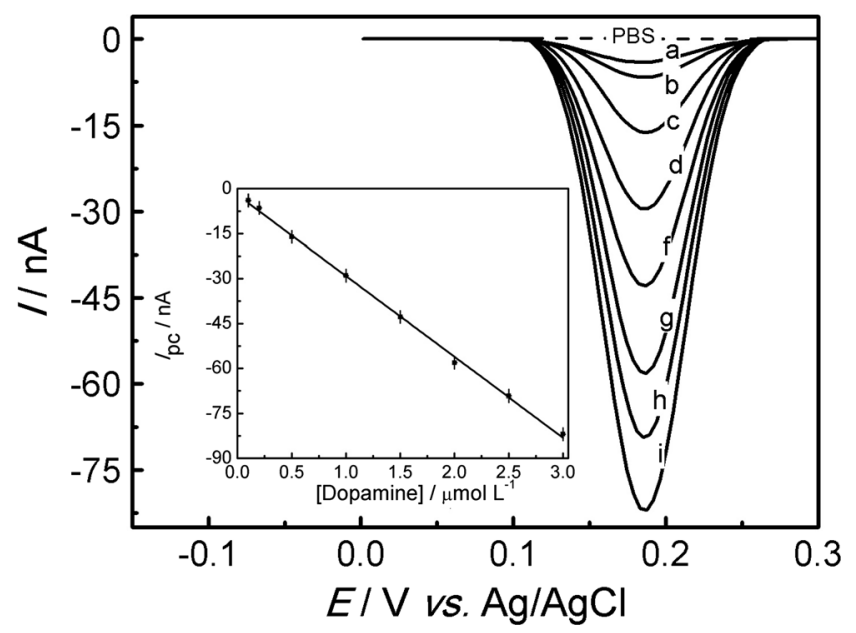

Fig. 7 DPV voltammograms for $\mathrm{GC} / \mathrm{rGO} / \mathrm{Lac}$ biosensor. The dopamine concentrations in $\mu \mathrm{M}$ are: (a) 0.1, (b) 0.2, (c) 0.5, (d) 1.0, (e) 1.5, (f) 2.0, $(g)$ 2.5, and (h) 3.0. Inset: Linear dependence of the cathodic peak current vs dopamine concentration laccase/multiwalled carbon nanotube-based biosensor $\left(0.40 \mu \mathrm{mol} \mathrm{L}^{-1}\right)$ [39].

Also, MWCNT/polypirrole/laccase film eletrocodeposited in earlier publication $\left(0.14 \mu \mathrm{mol} \mathrm{L}{ }^{-1}\right)$ [28] showed a similar LOD to our new biosensor electrochemical dispositive.

\section{Interferences}

Interferants, such as ascorbic acid (AA) and uric acid (UA), can cause a major problem when determining dopamine in biological fluids. Therefore, DPV experiments were conduct to evaluate whether acids could interfere with the electrochemical oxidation process of dopamine. An overlap process between the dopamine oxidation peak and the oxidation peak of the interfering substances studied was not observed. In addition, the interfering substances did not present a reduction process in the potential range studied. The effect of AA and $\mathrm{UA}$ on the dopamine $o$-quinone cathodic peak current was evaluated using $0.2 \mathrm{~mol} \mathrm{~L}^{-1}$ of PBS (pH 7.0) containing a fixed concentration of $1.0 \mu \mathrm{mol} \mathrm{L}{ }^{-1}$ of dopamine and sequential additions of $0.5,1.0$, and $2.0 \mu \mathrm{mol} \mathrm{L^{-1 }}$ of AA and UA. Recoveries of 106,109 , and $114 \%$ of dopamine $(n=3)$ were obtained when $0.5,1.0$, and $2.0 \mu \mathrm{mol} \mathrm{L} \mathrm{L}^{-1}$ of AA were added to each measurement, and recoveries of 97,102 , and $104 \%$ were obtained for UA, respectively. It is possible to observe that AA and UA interference increases the cathodic peak currents of the dopamine slightly. However, the interfering substances studied did not shift the dopamine $o$-quinone reduction peak, indicating that the analytical signal did not suffer from interference by the AA and UA, making it possible to determine dopamine in these samples using the standard addition procedure.

\section{Analysis of dopamine neurotransmitter in synthetic urine and plasmatic serum samples}

The developed biosensor was used for the quantification of dopamine in synthetic urine and plasmatic serum samples prepared as described in the "Materials and Methods" section. The corresponding DPV voltammograms obtained for the analysis of the synthetic urine sample are shown in Fig. 8, along with the respective standard addition plots. Dopamine determinations were performed in triplicate, without any treatment procedure, using the standard addition method. The results obtained (mean $\pm \mathrm{SD}$ ) for three determinations are presented in Table 1. Dopamine recoveries between 98.7 and $103.9 \%$ were obtained from synthetic urine samples $(n=3)$ for samples spiked with $0.5,1.0,1.5$, and $2.0 \mu \mathrm{mol} \mathrm{L}^{-1}$ of dopamine. For synthetic plasmatic serum sample $(n=3)$, recoveries between 97.2 and $104.5 \%$ dopamine were obtained for samples spiked with $0.5,1.0,1.5$, and $2.0 \mu \mathrm{mol} \mathrm{L}^{-1}$ of dopamine. 


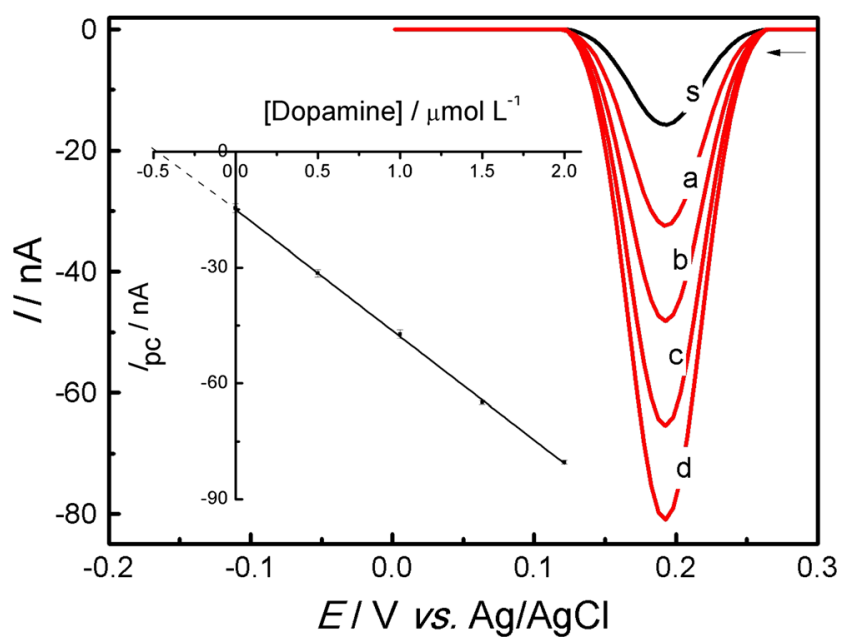

Fig. 8 DPV responses obtained on a $\mathrm{GC} / \mathrm{rGO} / \mathrm{Lac}$ biosensor for the determination of dopamine in urine sample: $(S)$ sample, $(a)$ sample plus $0.5 \mu \mathrm{mol} \mathrm{L}{ }^{-1}$ dopamine, (b) sample plus $1.0 \mu \mathrm{mol} \mathrm{L}{ }^{-1}$ dopamine, $(c)$ sample plus $1.5 \mu \mathrm{mol} \mathrm{L}{ }^{-1}$ dopamine, $(d)$ sample plus $2.0 \mu \mathrm{mol} \mathrm{L} \mathrm{L}^{-1}$ dopamine. Inset: linear dependence of the peak current with dopamine concentrations

There were no significant differences between the found and added concentrations of dopamine, indicating that the $\mathrm{GC} / \mathrm{rGO} / \mathrm{Lac}$ biosensor can be successfully used for the determination of dopamine in the analyzed samples under the optimized conditions and using the standard addition approach.

\section{Conclusion}

Biosensors based on the combination of graphene oxide or reduced graphed oxide and laccase were evaluated and successfully applied in the determination of dopamine in urine and plasmatic serum samples. The SEM images and electrochemical characterization showed that when the biocomposite was prepared using $\mathrm{rGO}$, the laccase enzyme was immobilized efficiently, increasing the analytical signal of dopamine by a factor of approximately two compared to the sensor prepared in the absence of laccase, namely GC/rGO.

Table 1 Results for the determination of dopamine in urine and plasmatic serum samples by DPV proposed method

\begin{tabular}{llllll}
\hline Repetition & \multicolumn{2}{l}{ Dopamine $\left(\mu \mathrm{mol} \mathrm{L}^{-1}\right)$} & & \multicolumn{2}{l}{ Relative errors $(\%)$} \\
\cline { 2 - 3 } \cline { 5 - 6 } \cline { 5 - 6 } & Urine & Plasmatic serum & & $\mathrm{E}_{1}$ & $\mathrm{E}_{2}$ \\
\hline 1 & 0.549 & 0.545 & 9.8 & 9.0 \\
2 & 0.546 & 0.540 & 9.2 & 8.0 \\
3 & 0.485 & 0.548 & & -3.0 & 9.6 \\
Mean $\pm \mathrm{SD}$ & $0.527 \pm 0.036$ & $0.544 \pm 0.004$ & & \\
\hline
\end{tabular}

$\mathrm{E}_{1}$ : DPV vs. urine added (DPV-added/added) $\times 100 \%$

$\mathrm{E}_{2}$ : DPV vs. plasmatic serum added (DPV-added/added) $\times 100 \%$
On the other hand, when the GO was used, the laccase enzyme was not immobilized properly, due the absence of structural defects on $\mathrm{GO}$ and more functional groups that can interfere in the electron transport, leading to the lowest analytical signal for dopamine.

The immobilization of $\mathrm{rGO} / \mathrm{Lac}$ film onto the surface of the GC electrode is very fast and practical, does not require any mediator or cross-linking agents, and presents an excellent analytical device for analysis of neurotransmitter in biological samples of interest.

Acknowledgements The authors would like to acknowledge the financial support of FAPESP (grant nos. 2015/02136-2 and 2015/09383-5) and the LMA-IQ for FEG-SEM facilities.

\section{References}

1. Thévenot DR, Toth K, Durst RA, Wilson GS (2001) Electrochemical biosensors: recommended definitions and classification. Biosens Bioelectron 16:121-131

2. Eggins BR (2002) Chemical sensors and biosensors first ed. Wiley, England

3. Collings AF, Caruso F (1997) Biosensors: recent advances. Rep Prog Phys 60:1397-1445

4. Junior LC, Lyons C (1962) Electrode systems for continuous monitoring in cardiovascular surgery. Ann N Y Acad Sci 102:29-45

5. Newman JD, Setford SJ (2006) Enzymatic biosensors. Mol Biotechnol 32:249-268

6. Datta S, Christena LR, Rajaram YRS (2013) Enzyme immobilization: an overview on techniques and support materials. Biotech 3:19

7. Ramirez P, Mano N, Andreu R, Ruzgas T, Heller A, Gorton L, Shleev S (2008) Direct electron transfer from graphite and functionalized gold electrodes to T1 and T2/T3 copper centers of bilirubin oxidase. Biochim Biophys Acta Bioenerg 1777:1364-1369

8. Geim AK (2009) Graphene: status and prospects. Science 324: $1530-1534$

9. Stoller MD, Park S, Zhu Y, An J, Ruoff RS (2008) Graphene-based ultracapacitors. Nano Lett 8:3498-3502

10. Yoo E, Kim J, Hosono E, Zhou HS, Kudo T, Honma I (2008) Large reversible Li storage of graphene nanosheet families for use in rechargeable lithium ion batteries. Nano Lett 8:2277-2282

11. Seger B, Kamat PV (2009) Electrocatalytically active grapheneplatinum nanocomposites. Role of 2-D carbon support in PEM fuel cells. J Phys Chem C 113:7990-7995

12. Wu JB, Becerril HA, Bao ZN, Liu ZF, Chen YS, Peumans P (2008) Organic solar cells with solution-processed graphene transparent electrodes. Appl Phys Lett 92:263302

13. Cincotto FH, Moraes FC, Machado SAS (2014) Graphene nanosheets and quantum dots: a smart material for electrochemical applications. Chem Eur J 20:4746-4753

14. Park S, Ruoff RS (2009) Chemical methods for the production of graphenes. Nat Nanotechnol 4:217-224

15. Geim AK, Novoselov KS (2007) The rise of graphene. Nat Mater 6: 183-191

16. Lee C, Wei X, Kysar JW, Hone J (2008) Measurement of the elastic properties and intrinsic strength of monolayer graphene. Science 321:385-388

17. Service RF (2009) Carbon sheets an atom thick give rise to graphene dreams. Science 324:875-877 
18. Balandin AA, Ghosh S, Bao W, Calizo I, Teweldebrhan D, Miao F, Lau CN (2008) Superior thermal conductivity of single-layer graphene. Nano Lett 8:902-907

19. Schniepp HC, Li JL, McAllister MJ, Sai H, Herrera-Alonso M, Adamson DH, Prudhomme RK, Car R, Saville DA, Aksay IA (2006) Functionalized single graphene sheets derived from splitting graphite oxide. J Phys Chem B 110:8535-8539

20. Stankovich S, Dikin DA, Piner RD, Kohlhaas KA, Kleinhammes A, Jia Y, Wu Y, Nguyen ST, Ruoff RS (2007) Synthesis of graphene-based nanosheets via chemical reduction of exfoliated graphite oxide. Carbon 45:1558-1565

21. Mei LP, Feng JJ, Wu L, Zhou JY, Chen JR, Wang AJ (2015) Novel phenol biosensor based on laccase immobilized on reduced graphene oxide supported palladium-copper alloyed nanocages. Biosens Bioelectron 74:347-352

22. Cincotto FH, Canevari TC, Machado SAS, Sanchez A, Barrio MAR, Villalonga R, Pingarron (2015) Reduced graphene oxide$\mathrm{Sb} 2 \mathrm{O} 5$ hybrid nanomaterial for the design of a laccase-based amperometric biosensor for estriol. Electrochim Acta 147:332-339

23. Boujakhrout A, Falcao SJ, Ruiz PM, Sanchez A, Diez P, Pingarron JM, Villalonga R (2016) Novel reduced graphene oxide-glycol chitosan nanohybrid for the assembly of an amperometric enzyme biosensor for phenols. Analyst 141:4162

24. Hong SG, Kim JH, Kim RE, Kwon SJ, Kim DW, Jung HT, Dordick JS, Kim J (2016) Immobilization of glucose oxidase on graphene oxide for highly sensitive biosensors. Biotechnol Bioprocess Eng 21:573-579

25. Xiang L, Yuqing L, Yu P, Su L, Mao L (2007) Laccase-catalyzed oxidation and intramolecular cyclization of dopamine: a new method for selective determination of dopamine with laccase/carbon nanotube-based electrochemical biosensors. Electrochim Acta 52: 4144-4152

26. Bergquist J, Sciubisz A, Kaczor A, Silberring J (2002) Catecholamines and methods for their identification and quantitation in biological tissues and fluids. J Neurosci Methods 113:1-13

27. Missale C, Nash SR, Robinson SW, Jaber M, Caron MG (1998) Dopamine receptors: from structure to function. Physiol Rev 78: 189-225

28. Cesarino I, Galesco HV, Machado SAS (2014) Determination of serotonin on platinum electrode modified with carbono nanotubes/ polypyrrole/silver nanoparticles nanohybrid. Mater Sci Eng C 40: $49-54$
29. Laube N, Mohr B, Hesse AJ (2001) Laser-probe-based investigation of the evolution of particle size distributions of calcium oxalate particles formed in artificial urines. J Cryst Growth 233:367-374

30. Cesarino I, Cincotto FH, Machado SAS (2015) A synergistic combination of reduced graphene oxide and antimony nanoparticles for estriol hormone detection. Sensors Actuators B 210:453-459

31. Gong Y, Li D, Fu Q, Pan C (2015) Influence of graphene microstructures on electrochemical performance for supercapacitors. Prog Nat Sci 25:379-385

32. Casero E, Parra-Alfambra AM, Petit-Domínguez MD, Pariente F, Lorenzo E, Alonso C (2012) Differentiation between graphene oxide and reduced graphene by electrochemical impedance spectroscopy (EIS). Electrochem Commun 20:63-66

33. Cesarino I, Galesco HV, Moraes FC, Lanza MRV, Machado AS (2013) Biosensor based on electrocodeposition of carbon nanotubes/polypyrrole/laccase for neurotransmitter detection. Electroanalysis 25:394-400

34. Gardner DG (2011) Greenspan's basic \& clinical endocrinology, Appendix: Normal Hormone Reference Ranges, ninth edn. The McGraw-Hill Companies, New York

35. Sun W, Yang M, Jiao K (2007) Electrocatalytic oxidation of dopamine at an ionic liquid modified carbon paste electrode and its analytical application. Anal Bioanal Chem 389:1283

36. Yang L, Liu S, Zhang Q, Li F (2012) Simultaneous electrochemical determination of dopamine and ascorbic acid using AuNPs@polyaniline core-shell nanocomposites modified electrode. Talanta 89:136

37. Izaoumen N, Cubillana-Aguilera LM, Naranjo-Rodriguez I, de Cisneros JLHH, Bouchta D, Temsamani KR, Santander JMP (2009) $\beta$-Sonogel-carbon electrodes: a new alternative for the electrochemical determination of catecholamines. Talanta 78:370

38. Xiang L, Lin Y, Yu P, Su L, Mao L (2007) Laccase-catalyzed oxidation and intramolecular cyclization of dopamine: a new method for selective determination of dopamine with laccase/carbon nanotube-based electrochemical biosensors. Electrochim Acta 52: 4144

39. Shanbhag D, Kindu K, Aarathy AR, Ramesh M, Sreejesh M, Nagaraja HS (2017) Hydrothermally synthesized reduced graphene oxide and Sn doped manganese dioxide nanocomposites for supercapacitors and dopamine sensors. Mater Today Energy 4: $66-74$ 